\title{
The electroretinogram: a useful tool for evaluating age-related macular disease?
}

\author{
Emma J. Berrow - Hannah E. Bartlett • \\ Frank Eperjesi · Jonathan M. Gibson
}

Received: 22 September 2009/ Accepted: 2 March 2010

Springer-Verlag 2010

\begin{abstract}
With an ageing population, the number of age-related macular disease (ARMD) cases will inevitably rise. This gives greater impetus for the need to identify the disease earlier and assess treatments to slow disease progression. Differing electroretinogram (ERG) modalities have been reviewed in relation to the objective assessment of retinal function in ARMD and for monitoring the effectiveness of clinical interventions. Conflicting results have been found with regard to the efficacy of ERG findings in the investigation of ARMD in previous years. The newer multifocal ERG paradigm provides spatial topographical information about retinal function in ARMD. It has shown promising results in monitoring effectiveness of clinical interventions and studies are continuing in this area. Better knowledge of retinal function in ARMD may lead to enhanced treatments at each phase of the disease.
\end{abstract}

E. J. Berrow (\&) H. E. Bartlett F. Eperjesi J. M. Gibson

Ophthalmic Research Group, School of Life and Health Sciences, Aston University, Birmingham B4 7ET,

United Kingdom

e-mail: berrowej@aston.ac.uk

E. J. Berrow J. M. Gibson

Heart of England NHS Trust, Birmingham,

United Kingdom

Published online: 16 March 2010
Keywords Electroretinography Maculopathy Age-related macular degeneration Multifocal electroretinogram

\section{Introduction}

In the majority of clinical studies of ARMD, visual acuity is used as a measure of macular function. However, this is far from ideal as it assesses one small area of the retina, does not provide an overall measure of macular function and relies on subjective patient responses. It is important to identify individuals who are at most risk of developing the ARMD, so that interventions and lifestyle modifications can be targeted appropriately. In asymptomatic eyes, sensitive, reproducible measures of macular function are important to highlight the earliest signs of ARM. The objectivity and the topographical mapping that multifocal electroretinography (mfERG) provides allows for assessment of localised retinal cell function deficits in ARM over time. Evidence also suggests that mfERG can be used to monitor effectiveness of surgical and clinical intervention. This review enumerates the efficacy of various types of electroretinogram (ERG) for assessing retinal function in ARMD.

Age-related macular degeneration (AMD) is the leading cause of visual loss in the developed world [1]. Age-related maculopathy (ARM) is characterised 
by drusen $(C 63 \mathbf{I m})$ with or without retinal pigment epithelium (RPE) changes and often precedes AMD. The term 'age-related macular disease (ARMD)' encompasses both ARM and AMD [2].

The RPE phagocytises the outer segment discs of the photoreceptors and is a point of metabolite and waste exchange, which is considered crucial to retinal function [3]. The earliest signs of ARMD are seen as variation in the pigmentation of the RPE, with or without the presence of drusen [4]. Oxidative stress may cause injury and inflammation to the RPE and choriocapillaris leading to an altered extracellular matrix, affecting nutrient supply to the RPE and retina, possibly further damaging the RPE and retina, leading to the retinal atrophy seen in AMD [5]. Ophthalmic electrophysiology can be used to measure the function of the choroid, RPE and the photoreceptor layer [6] and has therefore been shown to be a good means of objectively quantifying retinal function. RPE changes seen in AMD can be measured by the electrooculogram (EOG). Electroretinography assesses photoreceptor and post-receptoral retinal function. The differing ERG techniques are easily and non-invasively obtained with an active corneal electrode, reference electrode and ground electrode where electrical activity within the retina is studied using presentation of visual stimuli. Different stimuli used for differing ERG techniques allow for functional quantification of various retinal cells, each of which is discussed in the following sections.

\section{Full-field electroretinogram (ERG)}

The full-field or flash ERG (ffERG) generally consists of a negative deflection, called the a-wave, which is mainly associated with the photoreceptors and a positive b-wave, thought to be produced by ON bipolar cell depolarisation. Scotopic ffERGs elicit rod-dominated photoreceptor function responses and photopic conditions elicit cone-function responses. A 30-Hz light stimulus ERG also provides information about cone function, whilst oscillatory potentials reflect amacrine cell function [7]. ARMD can subtly affect areas of the retina unseen on clinical fundoscopy due to generalised retinal ischaemia [8] and altered retinal nutrient and waste exchange [5], thus ffERG changes may be apparent when ophthalmoscopy findings show very little.
The ffERG gives a massed retinal electrical response to a light stimulus but does not provide spatial retinal information. Thus, small retinal lesions such as those seen in ARM may be missed by ffERG, and so there have been contradictory findings reported for the appropriateness of using ffERG in the assessment of the condition [9-12] Holopigian et al. examined the effect of normal ageing, ARM and AMD on the ffERG. They demonstrated reduction of amplitudes and increase in implicit times of the ffERG over time with increasing age for normal subjects, as well as those with ARM and AMD under photopic and scotopic conditions [12]. Similarities between older normal subjects and those with ARM highlight the importance of using age-matched normals for comparison when observing older subjects with ARMD. These results correlated with the findings of other studies showing a decrease in rod and cone ERG amplitudes with age [13] and a slowed inactivation of phototransduction in rod photoreceptors with age when measuring the recovery of the a-wave using a paired flash ERG technique [9]. Marcus et al. [11] studied the b-wave of the ERG in 24 eyes of 12 subjects with ARMD and found low to normal b-wave amplitudes in diseased eyes and no correlation with clinical morphology. However, there was no control group comparison.

Along with reduced and delayed photopic conedominated a-wave responses, scotopic rod-dominated a- and b-wave responses have been examined in ARMD using the ffERG. These were also reduced and delayed, suggesting that ARMD affects rod as well as cone photoreceptors [10]. A review by Scullica and Falsini [14] identified that studies of retinal function in ARM and AMD have found substantial impairment of rod photoreceptor function. Inconsistency exists in the literature about the value of ffERG in ARMD. As the ffERG is a massed response, the sensitivity of the test is limited when trying to assess small lesions as observed in ARM [15].

\section{Pattern ERG}

The pattern ERG (PERG) occurs with pattern reversal stimulation, typically a checkerboard pattern of mean overall luminance, which isolates non-linear retinal responses while cancelling linear responses [16]. This

\section{3}


gives a direct measure of ganglion cell function and allows discrimination between optic nerve and macular disease [17]. Pattern ERG abnormalities have been seen in AMD and reduced PERG P50 amplitudes have been observed in maculopathies [17]. The PERG has been shown to be abnormal in macular dysfunction when there is no detectable change in the ffERG [18]. Since the PERG measures ganglion cell function [17] and ganglion cell function remains relatively preserved in AMD [19], it may be argued that PERG does not provide sufficient information about retinal function in ARMD, especially in ARM when only small areas of drusen are seen. The PERG elicits an inner retinal response whereas ARMD is a retinal degeneration primarily affecting the RPE and the choriocapillaris [12].

The PERG has been effective at assessing retinal function in AMD when clinical interventions are undertaken. Neveu et al. [20] demonstrated that a detectable PERG prior to photodynamic therapy (PDT) in eyes with choroidal neovascularisation (CNV) was the single best indicator for improvement in visual acuity following treatment. However, in ARM, the area of retinal lesion is usually smaller than the area of PERG recording making the PERG less effective at monitoring ARM compared to angiography. The PERG fails to provide any spatial retinal information. Another study examining PERG at the early stages of PDT for CNV showed a reduction in amplitudes and delay in latencies of the P50 and N95 soon after PDT which resolved at 1 month [21]. Mackay et al. [19] assessed longer term changes to the PERG over 12 months and found that the P50 and N95 amplitude reduced over the 12 months, without recovery. The P50 latency reduced over the year but then increased at 12 months. However, this finding was not statistically significant.

\section{Focal ERG}

Unlike the ffERG, the focal ERG (fERG) has the ability to specifically stimulate the fovea-useful when evaluating macular disease [22, 23]. A flickering light stimulus is utilised to stimulate the macular region and measures macular cone photoreceptor and bipolar cell function [24]. Although there is no international procedural standard set for undertaking this ERG technique, a number of varying techniques for recording fERG have been described in the literature. Differing field sizes (3-18) and light stimulus frequencies have been used. Seiple et al. [25] examined retinal function in ARMD using a range of stimulus frequencies $(10-60 \mathrm{~Hz})$. This work showed fERG amplitude losses at high and low frequencies in patients with macular disease, but relative sparing of the mid-temporal frequencies although the type and severity of ARMD was not noted within the results or separated out from other macular diseases.

Research on fellow eyes of patients with unilateral CNV has suggested that these eyes have a normal foveal cone number but abnormal cone function, indicated by delayed implicit times. Results were adjusted for age, gender, iris pigmentation and spherical equivalent [26]. Another study confirmed these findings and is postulated to be due outer retinal ischaemia [27]. Normal fERG phase but decreasing amplitudes have been documented with increasing severity of non-exudative AMD [28].

Nutritional supplementation and its effects on macular function have been investigated in subjects with ARM and age-matched normals. Falsini and colleagues [29] found that at 180 days, normal and ARM eyes showed an increase in fERG amplitudes after vitamin $\mathrm{E}$ and nicotinamide supplementation. At 360 days, amplitudes were maintained.

Binns and Margrain [30] proposed a fERG photostress modality to examine retinal function in ARM, using intense light adaptation to bleach the retina, followed by periodical fERG to examine the recoverability of retinal function and determine the rate of photopigment regeneration. Retinal function recovery rate was slower in those with ARM compared to controls suggesting impairment in the ability of the outer retina to regenerate cone photopigment.

The effect of age on the fERG has been detailed, showing decreasing amplitude with increasing age [23, 26] and increasing fERG implicit times [26], stressing the need for age-matched controls when investigating ARM and AMD with fERG.

Focal ERG is useful for assessing retinal function in ARM and AMD. However, good fixation is required and it is limited to a single area, thus giving no information about multiple areas of retinal function. Also, no international procedural standard has yet been determined. 


\section{Multifocal ERG}

The multifocal ERG (mfERG), developed by Sutter and Tran [31], is based on a pseudorandom M-sequence stimulation technique that allows simultaneous recording of ERGs from many retinal areas at once [32]. Like PERG, fERG and ffERG, it is an objective measurement of retinal function but in contrast to these tests the mfERG allows simultaneous measurements of multiple responses at different retinal locations [33, 34]. The first-order kernel of the mfERG waveform comprises of a negative N1 component, a positive $\mathrm{P} 1$ component and a negative N2 component. Hood's very comprehensive literature on mfERG suggests that mfERG responses are similar to the ffERG in that the N1 of the first-order kernel of the mfERG is cone-driven (as in a photopic ffERG) and that the P1 contains responses from the bipolar cells [35]. The mfERG is dominated by bipolar cell activity and so a disease that substantially decreases the mfERG amplitude must therefore be acting at or before the bipolar response [7]. The firstorder kernel is the most commonly measured parameter of the mfERG. The mfERG also contains a second order kernel which originates from induced components of the inner retina, more details of which can be understood in the work of Sutter [36-38]. The mfERG maps retinal function within the central $30-50$ of the retina and good fixation is required for accurate results, suggesting it may be better suited to assessment of retinal function in ARM where central vision is preserved.

Various studies have reported the efficacy of the mfERG in the assessment of ARMD [6, 19, 20, 29, 33, 39-58].

Eyes with ARM have been found to have reduced foveal mfERG P1 amplitudes and increased N1 latencies when compared with age-matched normal controls [46]. Interestingly, asymptomatic fellow eyes of the ARM eyes in this study also exhibited the same findings, suggesting that the mfERG may be a sensitive means of detecting early ARM changes. Feigl et al. [59], in contrast, found no such correlation, possibly attributable to non-uniform use of grading and classification systems and varying age range of the participants used in the different studies.

Research comparing the mfERG between exudative AMD, non-exudative ARM and normal controls has been undertaken [44] demonstrating reduction in the P1 and N1 amplitudes of both CNV and ARM eyes when compared with controls. However, although the average age of the CNV and ARM groups were similar in this study (64.4 and 66.5 years, respectively), the control group was younger (57.7 years). This may account for some amplitude reduction due to ageing influence on the mfERG $[60,61]$. Seiple et al. [62] demonstrated a significant linear relationship of $10.5 \%$ reduction in the $\mathrm{N} 1$ to $\mathrm{P} 1$ amplitude per decade, emphasising the importance of using age-matched controls when interpreting mfERG results.

The mfERG guidelines described by the International Society for Clinical Electrophysiology of Vision (ISCEV) [63], measures cone function. However, rod-mediated mfERG can be recorded after dark adaptation. It is time consuming with poorer signalto-noise ratios than cone-mfERGs [64]. A study to compare rod- and cone-mediated mfERG in ARM showed reduced N1 and P1 amplitudes in ARM when compared to controls in both rod- and cone-mediated mfERGs [47]. Delayed rod-mediated mfERG P1 implicit times in ARM eyes were reported when compared with age-matched normal controls [50, 52, 53], implying that both rod and cone function is affected in ARM. However, further work using larger sample sizes would provide more definitive rodmfERG information, as to date conflicting results have been demonstrated.

Interesting work has been undertaken on the use mfERG to investigate the role of ischaemia in ARM. Hypoxia has been experimentally induced in younger and older healthy eyes resulting in a reduction in central and peripheral neuroretinal function indicated by reduced mfERG response densities [41, 65, 66]. This supports the hypothesis that post-receptoral vulnerability occurs during reduced oxygenation and ischaemia [52, 67].

Differing mfERG paradigms have been used to evaluate rod and cone systems in ARM. Global-flash mfERGs have been used in an attempt to overcome some of the conflicting findings that have been observed with the conventional mfERG and to better reflect adaptation deficits in ARM [51]. The findings indicate that the global-flash mfERG detects reduced adaptation responses before the conventional mfERG. Thus, it could be argued that global-flash mfERG may be more beneficial in identifying ARM sooner than the standard mfERG. More research is necessary to consolidate this hypothesis.

\section{3}


The slow flash mfERG is another paradigm that has been subtracted from the conventional fast flicker mfERG to assess non-linear adaptive components within the retina in ARM [48]. Interestingly, neither conventional mfERG nor slow flash mfERGs discriminated between the ARM group and age-similar controls. However, the difference between the two paradigms showed a reduced late component waveform in the ARM group compared to the control group suggesting post-receptoral adaptation abnormalities in the ARM group.

Comparison between the conventional cone-mediated mfERG response and morphological changes in ARM have been examined [40, 49, 68], with outcomes suggesting slight increase in delayed implicit time with drusen progression, drusen regression with increasing RPE changes and in stable drusen. After more than 2 years, the responses became more delayed with reduced response density. The mfERG changes were not limited to the drusen areas in these studies, suggesting retinal function does not correlate directly with morphology in ARM.

The objectivity of the mfERG in assessing retinal function correlates well with subjective macular function tests in ARM and AMD [39], such as colour vision [49] and microperimetry testing [69] and suggests they may be significantly related to retinal function in the cone-mediated mfERG in ARM.

Multifocal ERG in clinical intervention studies

mfERG has been investigated as a tool for assessing retinal function before and after PDT, a widespread treatment for predominant classic CNV prior to the introduction of intravitreal ranibizumab and bevacizumab (Table 1).

Palmowski et al. [57] compared retinal function pre- and post-PDT in 16 eyes and found that after PDT the mfERG showed focal improvements in 13 eyes. In 10 eyes, focal retinal function deteriorated in some locations. At 15 weeks, some areas of the mfERG did not demonstrate any improvement when compared with mfERGs obtained at 3 weeks postPDT. They concluded that improvement in parafoveal function can be seen with mfERG and deemed it a suitable tool in assessing retinal function in AMD.

Short-term mfERG changes were assessed in 17 eyes with CNV before and after PDT with verteporfin by Jiang et al. [56] The mfERG latencies and response amplitude densities remained largely unchanged within 3 days, and at 1 week post-PDT with verteporfin when compared with pre-PDT mfERG. Their data suggests that verteporfin therapy may not result in adverse effects within the outer retina, in contrast to other histopathological studies assessing verteporfin and PDT in the monkey retina [70].

Multifocal ERG recordings were performed before PDT, and at 4 days, 2 weeks and 1 month after PDT with verteporfin in a study by Lai et al. [42]. Their research showed a transient impairment in retinal function that resolved after 1 month. In contrast to the work by Jiang et al., there was a change at 4 days post-PDT with reduced $\mathrm{N} 1$ and $\mathrm{P} 1$ response amplitude densities and increased P1 latencies. However, Lai's study contained only three AMD eyes with $\mathrm{CNV}$, the other fourteen eyes being a mixture of myopic CNV, idiopathic CNV, polypoidal choroidal vasculopathy and central serous chorioretinopathy.

Studies at baseline and 6 weeks post-PDT were assessed with mfERG by Ruether et al. [71] showing a trend towards reduced P1 amplitudes and delayed latency, although these effects were not statistically significant and comparison to a non-treated group did not occur.

Catala-Mora et al. [72] observed mfERG changes over a longer period post-PDT in twenty-three eyes. At two and six months after treatment, the N1 and P1 amplitudes did not change and even improved in the more peripheral areas tested. They concluded that mfERG offers interesting non-subjective information about retinal sensitivity in macular diseases treated with PDT.

Mackay et al. [58] examined the use of mfERG as a predictor of vision maintenance post-PDT in neovascular AMD using logistic regression models. Patients with an average of 6/30 vision were less likely to respond to PDT than those with poor vision. Relatively good contrast sensitivity and large central mfERGs increased the probability of a response to PDT. In a further study, mfERG was assessed in preand post-PDT in CNV. They found P1 response amplitude density increased at 6 months and then returned to baseline at 12 months [19]. Work undertaken by Moschos et al. [73] demonstrated that although at 6 months post-PDT $70 \%$ of vision remained stable, there was a demonstrable reduction of mfERG response amplitude density, highlighting 


\begin{tabular}{|c|c|c|c|c|c|c|c|c|}
\hline Reference & Sample size & $\begin{array}{l}\text { Age in years } \\
\text { Mean/range }\end{array}$ & ARMD status & $\begin{array}{l}\text { Visual acuity } \\
\text { pre-PDT }\end{array}$ & $\begin{array}{l}\text { Mean mfERG } \\
\text { findings pre-PDT }\end{array}$ & $\begin{array}{l}\text { Follow-up } \\
\text { duration after } \\
\text { PDT }\end{array}$ & $\begin{array}{l}\text { Visual acuity } \\
\text { post-PDT }\end{array}$ & $\begin{array}{l}\text { Mean mfERG } \\
\text { findings post- } \\
\text { PDT }\end{array}$ \\
\hline $\begin{array}{l}\text { Palmowski et al. Influence } \\
\text { of photodynamic therapy } \\
\text { in choroidal } \\
\text { neovascularization on } \\
\text { focal retinal function } \\
\text { assessed with the } \\
\text { multifocal } \\
\text { electroretinogram and } \\
\text { perimetry. } \\
\text { Ophthalmology. 2002; } \\
\text { 109(10):1788-92. }\end{array}$ & $\begin{array}{l}16 \text { eyes of } 16 \\
\text { patients }\end{array}$ & Not stated & $\begin{array}{l}\text { Classic } \\
\text { neovascular } \\
\text { AMD }\end{array}$ & $\begin{array}{l}\text { Median } 0.2 \\
\text { range } \\
0.05-0.8\end{array}$ & $\begin{array}{l}\text { Scalar product (SP) } \\
\text { template used } \\
\text { thus no pre-PDT } \\
\text { mfERG } \\
\text { information given }\end{array}$ & 2-15 weeks & $\begin{array}{l}\text { Median } 0.3 \\
\text { range } \\
0.04-1.25\end{array}$ & $\begin{array}{l}\text { SP improved in } \\
16 \text { locations } \\
\text { SP reduced in } \\
11 \text { locations }\end{array}$ \\
\hline $\begin{array}{l}\text { Jiang et al. The changes of } \\
\text { multifocal } \\
\text { electroretinography in } \\
\text { the early stage of } \\
\text { photodynamic therapy } \\
\text { for choroidal } \\
\text { neovascularization. } \\
\text { Documenta } \\
\text { Ophthalmologica. 2003; } \\
\text { 107(2):165-70. }\end{array}$ & $\begin{array}{l}17 \text { eyes of } 16 \\
\text { patients }\end{array}$ & $55.2(25-76)$ & $\begin{array}{l}12 \text { exudative } \\
\text { AMD eyes } \\
\text { (11 cases) } \\
2 \text { myopic CNV } \\
3 \text { idiopathic } \\
\text { CNV }\end{array}$ & $\begin{array}{l}\text { Median 20/ } \\
25 \\
\text { Range 20/ } \\
25-20 / 125\end{array}$ & $\begin{array}{l}\text { Ring 1-6 N1 lat } \\
21.39 \\
\text { Ring 1-6 P1 lat } \\
40.29 \\
\text { Ring 1-6 N1 amp } \\
7.84 \\
\text { Ring 1-6 P1 amp } \\
17.44\end{array}$ & $\begin{array}{l}3 \text { days, } \\
7 \text { days }\end{array}$ & $\begin{array}{l}\text { Median } 20 / 25 \\
\text { range } 20 / \\
25-20 / 125\end{array}$ & $\begin{array}{l}\text { Ring 1-6 N1 lat } \\
21.58 \\
\text { Ring 1-6 P1 lat } \\
40.39 \\
\text { Ring 1-6 N1 } \\
\text { amp 7.91 } \\
\text { Ring 1-6 P1 } \\
\text { amp 17.63 } \\
\text { (at } 7 \text { days) }\end{array}$ \\
\hline $\begin{array}{l}\text { Ruether et al. Testing } \\
\text { central retinal function } \\
\text { with multifocal } \\
\text { electroretinography } \\
\text { before and after } \\
\text { photodynamic therapy. } \\
\text { Ophthalmologe. 2003; } \\
\text { 100(6):459-64. }\end{array}$ & $\begin{array}{l}25 \text { eyes of } 24 \\
\text { patients }\end{array}$ & $\begin{array}{c}71.3 \text { range } \\
\text { not given }\end{array}$ & $\begin{array}{l}12 \text { classic } \\
\text { subfoveal } \\
\text { Neovascular } \\
\text { AMD } \\
9 \text { Occult CNV } \\
\text { AMD } \\
4 \text { myopic CNV }\end{array}$ & $\begin{array}{l}\text { Mean } 0.22 \\
\text { range not } \\
\text { given }\end{array}$ & $\begin{array}{l}\text { Centre amp } 31.33 \\
\text { Ring } 1 \text { amp } 20.67 \\
\text { Ring } 2 \text { amp } 15.33\end{array}$ & 6 weeks & $\begin{array}{l}\text { Mean } 0.22 \\
\text { range not } \\
\text { given }\end{array}$ & $\begin{array}{l}\text { Centre amp } \\
26.33 \\
\text { Ring } 1 \mathrm{amp} \\
18.33 \\
\text { Ring } 2 \mathrm{amp} \\
13.33\end{array}$ \\
\hline $\begin{array}{l}\text { Moschos et al. Assessment } \\
\text { of macular function by } \\
\text { multifocal } \\
\text { electroretinogram in age- } \\
\text { related macular } \\
\text { degeneration before and } \\
\text { after photodynamic } \\
\text { therapy. J Fr Ophthamol. } \\
\text { [Article]. 2004 Nov; } \\
\text { 27(9):1001-6. }\end{array}$ & $\begin{array}{l}20 \text { eyes of } 20 \\
\text { patients }\end{array}$ & $\begin{array}{l}69.05 \text { (range } \\
30-80 \text { ) }\end{array}$ & $\begin{array}{l}\text { Classic } \\
\text { subfoveal } \\
\text { neovascular } \\
\text { AMD }\end{array}$ & $\begin{array}{l}\text { Mean } 21.35 \\
\text { range 1-49 } \\
\text { (ETDRS } \\
\text { number of } \\
\text { letters) }\end{array}$ & $\begin{array}{l}\text { Mean retinal } \\
\text { response amp } \\
\text { density area } \\
1=4.39 \text {, area } \\
2=2.11\end{array}$ & $\begin{array}{l}1 \text { week, } \\
3 \text { months, } \\
6 \text { months }\end{array}$ & $\begin{array}{l}\text { 17.6 range } \\
1-42 \\
\text { (ETDRS } \\
\text { number of } \\
\text { letters) }\end{array}$ & $\begin{array}{l}\text { Mean retinal } \\
\text { response amp } \\
\text { density area } \\
\begin{array}{l}1=2.24 \text { area } \\
2=1.07\end{array}\end{array}$ \\
\hline
\end{tabular}


Table 1 continued

\begin{tabular}{|c|c|c|c|c|c|c|c|c|}
\hline Reference & Sample size & $\begin{array}{l}\text { Age in years } \\
\text { Mean/range }\end{array}$ & ARMD status & $\begin{array}{l}\text { Visual acuity } \\
\text { pre-PDT }\end{array}$ & $\begin{array}{l}\text { Mean mfERG } \\
\text { findings pre-PDT }\end{array}$ & $\begin{array}{l}\text { Follow-up } \\
\text { duration after } \\
\text { PDT }\end{array}$ & $\begin{array}{l}\text { Visual acuity } \\
\text { post-PDT }\end{array}$ & $\begin{array}{l}\text { Mean mfERG } \\
\text { findings post-PDT }\end{array}$ \\
\hline $\begin{array}{l}\text { Lai et al. Transient } \\
\text { reduction in retinal } \\
\text { function revealed by } \\
\text { multifocal } \\
\text { electroretinogram after } \\
\text { photodynamic therapy. } \\
\text { American Journal of } \\
\text { Ophthalmology. 2004; } \\
\text { 137(5):826-33. }\end{array}$ & $\begin{array}{l}17 \text { eyes } \\
\text { of } 17 \\
\text { patients }\end{array}$ & $50.5(29-75)$ & $\begin{array}{l}3 \text { AMD CNV } \\
4 \text { idiopathic } \\
\text { CNV } \\
4 \text { myopic CNV } \\
4 \text { polypoidal } \\
\text { choroidal } \\
\text { vasculopathy } \\
2 \text { central serous } \\
\text { chorioreti- } \\
\text { nopathy }\end{array}$ & $\begin{array}{l}\text { Median 20/ } \\
70 \text { range } \\
20 / 30-20 / \\
100\end{array}$ & $\begin{array}{l}\text { Central N1 amp } 9.97 \\
\text { Peripheral N1 amp } \\
6.93 \\
\text { Central P1 amp } 26.12 \\
\text { Peripheral P1 amp } \\
19.40\end{array}$ & $\begin{array}{l}4 \text { days, } \\
2 \text { weeks } \\
\text { and } \\
1 \text { month }\end{array}$ & $\begin{array}{l}\text { Median } 20 / 50 \\
\text { range } 20 / \\
30-20 / 100 \\
\text { at } 1 \text { month }\end{array}$ & $\begin{array}{l}\text { Central N1 amp } 9.49 \\
\text { Peripheral N1 amp } 6.52 \\
\text { Central P1 amp } 25.05 \\
\text { Peripheral P1 amp } 18.81 \\
\text { (at } 1 \text { month) }\end{array}$ \\
\hline $\begin{array}{l}\text { Feigl B et al. Dynamics of } \\
\text { retinal function after } \\
\text { multiple photodynamic } \\
\text { therapies in age-related } \\
\text { macular degeneration: A } \\
\text { report of cases. Doc } \\
\text { Ophthalmol. 2005 Apr } \\
\text { 24-29; 111(3):135-48. }\end{array}$ & $\begin{array}{c}5 \text { eyes of } 5 \\
\text { patients }\end{array}$ & $74(64-81)$ & 5 CNV AMD & $\begin{array}{l}\text { Median 6/38 } \\
\text { range } \\
6 / 19-6 / 60\end{array}$ & $\begin{array}{l}\text { Pre-treatment figures } \\
\text { not provided. Pre- } \\
\text { treatment mfERG } \\
\text { used as a waveform } \\
\text { template with } \\
\text { Matlab software to } \\
\text { compare with post- } \\
\text { treatment mfERG } \\
\text { values }\end{array}$ & $\begin{array}{l}1,2 \text { and } \\
3 \text { months }\end{array}$ & $\begin{array}{l}\text { Median 6/48 } \\
\text { range 6/38- } \\
6 / 60\end{array}$ & $\begin{array}{l}\text { Cone-mfERG: Central a- } \\
\text { scale }=1.0 \text { paracentral a- } \\
\text { scale }=1.3 \text { pericentral a- } \\
\text { scale }=1.3 \text { central t-scale } \\
=1.1 \text { paracentral } \text { t-scale } \\
=1.0 \text { pericentral t-scale } \\
=0.9 \text { (all numbers are } \\
\text { ratios at } \\
3 \text { months compared to } \\
\text { pre-treatment values) } \\
\text { Rod-mfERG: } \\
\text { Overall a-scale }=0.9 \\
\text { Overall t-scale }=0.9 \\
\text { (all numbers are ratios at } \\
2 \text { months compared to } \\
\text { pre-treatment values) }\end{array}$ \\
\hline $\begin{array}{l}\text { Catala-Mora et al. } \\
\text { Multifocal } \\
\text { electroretinogram and } \\
\text { age-related macular } \\
\text { degeneration. Arch Soc } \\
\text { Esp Oftalmol. 2005; } \\
\text { 80(7):395-404. }\end{array}$ & $\begin{array}{c}23 \text { eyes of } 22 \\
\text { patients }\end{array}$ & Not given & $\begin{array}{l}23 \text { classic } \\
\text { CNV AMD }\end{array}$ & $\begin{array}{l}\text { 20/21 } \\
\text { (colenbr- } \\
\text { ander) }\end{array}$ & $\begin{array}{l}\text { See post-PDT } \\
\text { column }\end{array}$ & $\begin{array}{l}2 \text { months, } \\
6 \text { months }\end{array}$ & $\begin{array}{l}\text { 20/17 } \\
\text { (colenbr- } \\
\text { ander) at } \\
6 \text { months }\end{array}$ & $\begin{array}{l}\text { Statistical significance } \\
\text { was reached for ring } 5 \\
\text { scalar product, ring } 3 \\
\text { and ring } 5 \text { P1 } \\
\text { amplitude, ring } 3 \text { P1 } \\
\text { latency and in ring } 5 \\
\text { N1 latency at } 6 \text { months } \\
\text { compared to pre } \\
\text { treatment values }\end{array}$ \\
\hline
\end{tabular}




\begin{tabular}{|c|c|c|c|c|c|c|c|c|}
\hline Reference & Sample size & $\begin{array}{l}\text { Age in years } \\
\text { Mean/range }\end{array}$ & ARMD status & $\begin{array}{l}\text { Visual acuity } \\
\text { pre-PDT }\end{array}$ & $\begin{array}{l}\text { Mean mfERG } \\
\text { findings pre-PDT }\end{array}$ & $\begin{array}{l}\text { Follow-up } \\
\text { duration after } \\
\text { PDT }\end{array}$ & $\begin{array}{l}\text { Visual acuity } \\
\text { post-PDT }\end{array}$ & $\begin{array}{l}\text { Mean mfERG } \\
\text { findings post-PDT }\end{array}$ \\
\hline $\begin{array}{l}\text { Mackay et al. Deficits in } \\
\text { the electroretinogram in } \\
\text { neovascular age-related } \\
\text { macular degeneration } \\
\text { and changes during } \\
\text { photodynamic therapy. } \\
\text { Documenta } \\
\text { Ophthalmologica. 2007; } \\
\text { 115:69-76. }\end{array}$ & $\begin{array}{l}50 \text { eyes of } 50 \\
\text { patients } \\
\text { plus } 13 \\
\text { control eyes }\end{array}$ & $\begin{array}{l}77.5(61-92) \\
\text { Patient } \\
72.8(56-88) \\
\text { control }\end{array}$ & $\begin{array}{l}43 \text { classic CNV } \\
\text { AMD } \\
7 \text { classic with } \\
\text { occult CNV } \\
\text { AMD }\end{array}$ & $\begin{array}{l}\text { Median } \\
\text { 6/37.5 } \\
\text { Patient } \\
\text { 6/6 control }\end{array}$ & $\begin{array}{l}\text { Pre-PDT } \\
\text { Central segment amp } \\
\text { deficit } 59.7 \\
\text { Ring } 2 \text { amp deficit } \\
13.6 \\
\text { Ring } 3 \text { amp deficit } \\
3.2 \text { when compared } \\
\text { to controls no } \\
\text { statistically } \\
\text { significant latency } \\
\text { deficit for any ring } \\
\text { when compared to } \\
\text { controls } \\
\text { Post-PDT the deficits } \\
\text { remain largely } \\
\text { unchanged }\end{array}$ & $\begin{array}{l}\text { During } \\
12 \text { months }\end{array}$ & Not given & $\begin{array}{l}\text { mfERG P1 response } \\
\text { amplitude density } \\
\text { increases at six moths } \\
\text { and returns to baseline } \\
\text { at } 12 \text { months }\end{array}$ \\
\hline $\begin{array}{l}\text { Mackay et al. Multifocal } \\
\text { electroretinography as a } \\
\text { predictor of maintenance } \\
\text { of vision after } \\
\text { photodynamic therapy } \\
\text { for neovascular age- } \\
\text { related macular } \\
\text { degeneration. } \\
\text { Documenta } \\
\text { Ophthalmologica. 2008; } \\
\text { 116(1):13-8. }\end{array}$ & $\begin{array}{l}39 \text { eyes of } 39 \\
\text { patients }\end{array}$ & $\begin{array}{l}77.1(74.7- \\
79.1)\end{array}$ & $\begin{array}{l}34 \text { classic CNV } \\
\text { AMD } \\
5 \text { classic with } \\
\text { occult }\end{array}$ & $\begin{array}{l}\text { Median } 48.0 \\
\text { letters } \\
\text { logMAR }\end{array}$ & $\begin{array}{l}\text { Ring } 1 \text { P1 amp } 18.5 \\
\text { Ring } 2 \text { P1 amb } 19.6 \\
\text { Ring } 3 \text { P1 amp } 17.1 \\
\text { Ring } 1 \text { P1 lat } 39.5 \\
\text { Ring } 2 \text { P1 lat } 37.8 \\
\text { Ring } 3 \text { P1 lat } 35.7\end{array}$ & $\begin{array}{c}12 \text { months } \\
\text { (VA not } \\
\text { mfERG) }\end{array}$ & $\begin{array}{l}59 \% \text { lost less } \\
\text { than } 15 \\
\text { letters on } \\
\text { the ETDRS } \\
\text { chart over } \\
12 \text { months }\end{array}$ & $\begin{array}{l}\text { Not undertaken- } \\
\text { mfERG undertaken } \\
\text { prior to PDT as a } \\
\text { predictor for vision } \\
\text { maintenance post- } \\
\text { PDT. Large central } \\
\text { mfERGs prior to PDT } \\
\text { increase the probability } \\
\text { of a response to PDT in } \\
\text { neovascular AMD }\end{array}$ \\
\hline
\end{tabular}

Amp amplitude in $\mathrm{nV} / \mathrm{deg}^{2}$, Lat latency in ms 
the need for objective measures of retinal integrity when monitoring the efficacy of clinical intervention.

Feigl et al. used the rod-mfERG and cone-mfERG to determine the effects of multiple PDT treatments in a case report of five eyes showing transient reduction in cone-mfERG waveforms and then recovery over time in all eyes and similar findings for rod-mfERG in four out of five eyes, possibly caused by choroidal hypoperfusion. However, baseline rod-mfERG responses were poor, very small and the test demanding for patients [74].

With the recent implementation of costly intravitreal ranibizumab treatment for AMD with $\mathrm{CNV}$, greater impetus has been given to looking at ways of diagnosing, monitoring and treating AMD earlier to preserve vision. In a study of nine patients who received intravitreal bevacizumab for the treatment of exudative AMD, mfERGs were performed pre- and post-treatment [55]. A linear relationship was found between visual acuity and P1 response amplitudes, suggesting that bevacizumab improved retinal function. mfERG parafoveal retinal response density improvement 3 months post-bevacizumab has been demonstrated in research by Moschos et al. [75] when studying eighteen eyes with CNV. Correlation between mfERG retinal response density in the central fifteen degrees and retinal thickness has been demonstrated in four eyes post-bevacizumab treatment, resulting in improvement of mfERG macular function responses with reduction in retinal thickness as measured by optical coherence tomography, although in this study ISCEV mfERG guidelines were replaced with a customised experimental m-sequence technique [76]. Ranibizumab efficacy has been investigated in a small study of three eyes using mfERG with a reduction in central and peripheral amplitudes being evident after three treatments when compared to agematched normal eyes [77]. Further studies are required in the area of anti-vascular endothelial growth factor (anti-VEGF) agents, both singularly and in combination treatments, to test the efficacy of different dosing regimes and the mfERG could have an important role for assessing retinal function within this area.

The role of nutrition in retinal health may prove to become an integral part in the management of ARM. Parisi et al. [54] looked at the influence of short-term carotenoid and antioxidant supplementation on retinal function in ARM. They demonstrated that in the central five degrees, ARM subjects treated with nutritional supplementation showed an increase in mfERG amplitudes after 6 months when compared with controls.

\section{Conclusion and future directions}

It is important to identify individuals who are at most risk of developing the ARMD, so that interventions and lifestyle modifications can be targeted appropriately. In asymptomatic eyes with normal visual acuity, sensitive but reproducible tests of macular function will become more important to detect the earliest signs of ARM. The objectivity and the topographical mapping of the mfERG allow localised retinal functional deficits in ARM can be observed over time. Evidence also suggests that mfERG can be used to monitor effectiveness of surgical and clinical intervention. Experimental mfERG techniques as discussed, have shown some interesting findings and although experimental at this stage, may provide additional information about the onset and progression of ARM with time. Complementary subjective measurement techniques such as microperimetry may document disease progression and treatment monitoring in macular function more effectively than visual acuity alone [78].

Acknowledgments The authors thank Dr Mohammad Laiquzzaman for helpful editorial comments.

Competing Interests None.

\section{References}

1. Klein R, Klein BEK, Tomany SC, Meuer SM, Huang GH (2002) Ten-year incidence and progression of age-related maculopathy. Ophthalmology 109:1767-1779

2. Bird AC, Bressler NM, Bressler SB, Chisholm IH, Coscas G, Davis MD, de Jong PTVM, Klaver CCW, Klein BEK, Klein R, Mitchell P, Sarks JP, Sarks SH, Soubrane G, Taylor HR, Vingerling JR (1995) An international classification and grading system for age-related maculopathy and age-related macular degeneration. Surv Ophthalmol 39:367-374

3. Kaur C, Foulds WS, Ling EA (2008) Blood-retinal barrier in hypoxic ischaemic conditions: basic concepts, clinical features and management. Prog Retin Eye Res 27:622-647

4. Moore DJ (1995) Age-related variation in the hydraulic conductivity of bruch's membrane. Invest Ophthalmol Vis Sci 36:1290-1297

5. Zarbin M (2004) Current concepts in the pathogenesis of age-related macular degeneration. Arch Ophthalmol 122:598-614 
6. Feigl B, Lovie-Kitchin J, Brown B (2005) Objective functional assessment of age-related maculopathy: a special application for the multifocal electroretinogram. Clin Exp Optom 88:304-312

7. Heckenlively JR, Arden GB (2006) Principles and practical of clinical electrophysiology of vision, 2nd edn. MIT press, Cambridge, MA

8. Grunwald JE, Metelitsina TI, DuPont JC, Ying GS, Maguire MG (2005) Reduced foveolar choroidal blood flow in eyes with increasing AMD severity. Invest Oph- thalmol Vis Sci 46:1033-1038

9. Jackson GR, McGwin JG, Phillips JM, Klein R, Owsley C (2006) Impact of aging and age-related maculopathy on inactivation of the a-wave of the rod-mediated electroret- inogram. Vision Res 46:1422-1431

10. Walter P, Widder RA, Luke C, Konigsfeld P, Brunner R (1999) Electrophysiological abnormalities in age-related macular degeneration. Graefes Arch Clin Exp Ophthalmol 237:962-968

11. Marcus M, Merin S, Wolf M, Feinsod M (1983) Electrophysiologic tests in assessment of senile macular degeneration. Ann Ophthalmol 15:235-238

12. Holopigian K, Seiple W, Greenstein V, Kim D, Carr RE (1997) Relative effects of aging and age-related macular degeneration on peripheral visual function. Optom Vis Sci

74:152-159

13. Birch DG, Anderson JL (1992) Standardized full-field electroretinography-normal values and their variation with age. Arch Ophthalmol 110:1571-1576

14. Scullica L, Falsini B (2001) Diagnosis and classification of macular degenerations: an approach based on retinal function testing. Doc Ophthalmol 102:237-250

15. Hogg RE, Chakravarthy U (2006) Visual function and dysfunction in early and late age-related maculopathy. Prog Retin Eye Res 25:249-276

16. Bach MHM (2006) The origin of the pattern electroretinogram. In: Heckenlively JR, Arden GB (eds) Principles and practical of clinical electrophysiology of vision, MIT Press, Cambridge, MA, pp 185-196

17. Holder GE (2001) Pattern electroretinography (PERG) and an integrated approach to visual pathway diagnosis. Prog Retin Eye Res 20:531-561

18. Trick GL (2003) Beyond visual acuity: new and complementary tests of visual function. Neurol Clin of $\mathrm{N}$ Am 21:363-386

19. Mackay AM, Brown MC, Hagan RP, Fisher AC, Grierson I, Harding SP (2007) Deficits in the electroretinogram in neovascular age-related macular degeneration and changes during photodynamic therapy. Doc Ophthalmol 115:69-76

20. Neveu MM, Tufail A, Dowler JG, Holder GE (2006) A comparison of pattern and multifocal electroretinography in the evaluation of age-related macular degeneration and its treatment with photodynamic therapy. Doc Ophthalmol 113:71-81

21. Oner A, Karakucuk S, Mirza E, Erkilic K (2005) The changes of pattern electroretinography at the early stage of photodynamic therapy. Doc Ophthalmol 111:107-112

22. Arden GB, Bankes JL (1966) Foveal electroretinogram as a clinical test. Br J Ophthalmol 50:740

23. Birch DG, Fish GE (1988) Focal cone electroretinogramsaging and macular disease. Doc Ophthalmol 69:211-220
24. Bankes JL (1967) The foveal electroretinogram. Trans Ophthalmol Soc U K 87:249-262

25. Seiple WH, Siegel IM, Carr RE, Mayron C (1986) Eval- uating macular function using the focal erg. Invest Oph- thalmol Vis Sci 27:1123-1130

26. Sandberg MA, Miller S, Gaudio AR (1993) Foveal cone ergs in fellow eyes of patients with unilateral neovascular age-related macular degeneration. Invest Ophthalmol Vis Sci 34:3477-3480

27. Remulla JFC, Gaudio AR, Miller S, Sandberg MA (1995) Foveal electroretinograms and choroidal perfusion characteristics in fellow eyes of patients with unilateral neovascular age-related macular degeneration. $\mathrm{Br} \mathrm{J}$ of Ophthalmol 79:558-561

28. Falsini B, Serrao S, Fadda A, Iarossi G, Porrello G, Cocco F, Merendino E (1999) Focal electroretinograms and fundus appearance in nonexudative age-related macular degeneration-quantitative relationship between retinal morphology and function. Graefes Arch Clin Exp Ophthalmol 237:193-200

29. Falsini B, Piccardi M, Iarossi G, Fadda A, Merendino E, Valentini P (2003) Influence of short-term antioxidant supplementation on macular function in age-related maculopathy. A pilot study including electrophysiologic assessment. Ophthalmology 110:51-60

30. Binns AM, Margrain TH (2007) Evaluating retinal function in age-related maculopathy with the erg photostress test. Invest Ophthalmol Vis Sci 48:2806-2813

31. Sutter EE, Tran D (1992) The field topography of erg components in man. 1 . The photopic luminance response. Vision Res 32:433-446

32. Sutter EE (1991) The fast m-transform-a fast computation of cross-correlations with binary m-sequences. SIAM J Comput 20:686-694

33. Palmowski AM, Sutter EE, Bearse MA, Fung W (1999) Multifocal electroretinography (mf-erg) in age-related macular degeneration. Ophthalmologe 96:166-173

34. Lai TYY, Chan WM, Lai RYK, Ngai JWS, Li HT, Lam DSC (2007) The clinical applications of multifocal elec- troretinography: a systematic review. Surv Ophthalmol 52:61-96

35. Hood DC (2000) Assessing retinal function with the multifocal technique. Prog Retin Eye Res 19:607-646

36. Sutter EE (2001) Imaging visual function with the multifocal m-sequence technique. Vision Res 41:12411255

37. Sutter E (2000) The interpretation of multifocal binary kernels. Doc Ophthalmol 100:49-75

38. Gerth C (2009) The role of the erg in the diagnosis and treatment of age-related macular degeneration. Doc Oph- thalmol 118:63-68

39. Parisi VM, Perillo LM, Tedeschi MM, Scassa CM, Gallinaro GB, Capaldo NB, Varano MM (2007) Macular function in eyes with early age-related macular degeneration with or without contralateral late age-related macular degeneration. Retin 27:879-890

40. Gerth C, Hauser D, Delahunt PB, Morse LS, Werner JS (2003) Assessment of multifocal electroretinogram abnormalities and their relation to morphologic characteristics in patients with large drusen. Arch Ophthalmol 121:14041414 


\section{3}


41. Feigl B (2007) Age-related maculopathy in the light of ischaemia. Clin Exp Optom 90:263-271

42. Lai TYY, Chan W-M, Lam DSC (2004) Transient reduction in retinal function revealed by multifocal electroretinogram after photodynamic therapy. Am J Ophthalmol 137:826-833

43. Kretschmann U, Seeliger M, Ruether K, Usui T, Zrenner E (1998) Spatial cone activity distribution in diseases of the posterior pole determined by multifocal electroretinography. Vision Res 38:3817-3828

44. Huang S, Wu D, Jiang F, Ma J, Wu L, Liang J, Luo G (2000) The multifocal electroretinogram in agerelated maculopathies. Doc Ophthalmol 101:115-124

45. Heinemann-Vernaleken B, Palmowski AM, Allgayer R, Ruprecht KW (2001) Comparison of different high reso- lution multifocal electroretinogram recordings in patients with age-related maculopathy. Graefes Arch Clin Exp Ophthalmol 239:556-561

46. Li J, Tso MOM, Lam TT (2001) Reduced amplitude and delayed latency in foveal response of multifocal electroretinogram in early age related macular degeneration. $\mathrm{Br} \mathrm{J}$ Ophthalmol 85:287-290

47. Chen CZ, Wu LZ, Wu DZ, Huang SZ, Wen F, Luo GW, Long SX (2004) The local cone and rod system function in early age-related macular degeneration. Doc Ophthalmol 109:1-8

48. Feigl B, Brown B, Lovie-Kitchin J, Swann P (2006) Postreceptoral adaptation abnormalities in early age-related maculopathy. Vis Neurosci 23:863-870

49. Feigl B, Brown B, Lovie-Kitchin J, Swann P (2004) Conemediated multifocal electroretinogram in early age-related maculopathy and its relationships with subjective macular function tests. Curr Eye Res 29:327-336

50. Feigl B, Brown B, Lovie-Kitchin J, Swann P (2006) The rod-mediated multifocal electroretinogram in aging and in early age-related maculopathy. Curr Eye Res 31:635-644

51. Feigl B, Brown B, Lovie-Kitchin J, Swann P (2005) Adaptation responses in early age-related maculopathy. Invest Ophthalmol Vis Sci 46:4722-4727

52. Feigl B, Brown B, Love-Kitchin J, Swann P (2005) Coneand rod-mediated multifocal electroretinogram in early age-related maculopathy. Eye 19:431-441

53. Feigl B, Brown B, Lovie-Kitchin J, Swann P (2005) Monitoring retinal function in early age-related maculop- athy: visual performance after 1 year. Eye 19:1169-1177

54. Parisi V, Tedeschi M, Gallinaro G, Varano M, Saviano S, Piermarocchi S (2008) Carotenoids and antioxidants in age-related maculopathy italian study: multifocal electroretinogram modifications after 1 year. Ophthalmology 115:324-333 e322

55. Karanjia R, Eng KT, Gale J, Sharma S, ten Hove MW (2008) Electrophysiological effects of intravitreal avastin (bevacizumab) in the treatment of exudative age-related macular degeneration. $\mathrm{Br} \mathrm{J}$ Ophthalmol 92: $1248-1252$

56. Jiang LB, Jin CJ, Wen F, Huang SZ, Wu DZ, Wu LZ (2003) The changes of multifocal electroretinography in the early stage of photodynamic therapy for choroidal neovascularization. Doc Ophthalmol 107:165-170

57. Palmowski AM, Allgayer R, Heinemann-Vernaleken B, Ruprecht KW (2002) Influence of photodynamic therapy in choroidal neovascularization on focal retinal function assessed with the multifocal electroretinogram and perimetry. Ophthalmology 109:1788-1792

58. Mackay AM, Brown MC, Grierson I, Harding SP (2008) Multifocal electroretinography as a predictor of maintenance of vision after photodynamic therapy for neovascular age-related macular degeneration. Doc Ophthalmol 116:13-18

59. Feigl B (2009) Age-related maculopathy-linking aetiology and pathophysiological changes to the ischaemia hypothesis. Prog Retin Eye Res 28:63-86

60. Nabeshima T, Tazawa Y, Mita M, Sano M (2002) Effects of aging on the first and second-order kernels of multifocal electroretinogram. Jpn J Ophthalmol 46:261-269

61. Mohidin N, Yap MKH, Jacobs RJ (1999) Influence of age on the multifocal electroretinography. Ophthalmic Physiol Optics 19:481-488

62. Seiple W, Vajaranant TS, Szlyk JP, Clemens C, Holopigian K, Paliga J, Badawi D, Carr RE (2003) Multifocal electroretinography as a function of age: the importance of normative values for older adults. Invest Ophthalmol Vis Sci 44:1783-1792

63. Hood DC, Bach M, Brigell M, Keating D, Kondo M, Lyons JS, Palmowski-Wolfe AM (2008) ISCEV guidelines for clinical multifocal electroretinography (2007 edition). Doc Ophthalmol 116:1-11

64. Hood DC, Wladis EJ, Shady S, Holopigian K, Li J, Seiple W (1998) Multifocal rod electroretinograms. Invest Ophthalmol Vis Sci 39:1152-1162

65. Feigl B, Stewart IB, Brown B, Zele AJ (2008) Local neuroretinal function during acute hypoxia in healthy older people. Invest Ophthalmol Vis Sci 49:807-813

66. Feigl B, Stewart I, Brown B (2007) Experimental hypoxia in human eyes: implications for ischaemic disease. Clin Neurophysiol 118:887-895

67. Feigl B, Brown B, Lovie-Kitchin J, Swann P (2007) Functional loss in early age-related maculopathy: the ischaemia postreceptoral hypothesis. Eye 21:689-696

68. Gerth C, Delahunt PB, Alam S, Morse LS, Werner JS (2006) Cone-mediated multifocal electroretinogram in agerelated macular degeneration-progression over a longterm follow-up. Arch Ophthalmol 124:345-352

69. Parisi V, Perillo L, Tedeschi M, Scassa C, Gallinaro G, Capaldo N, Varano M (2007) Macular function in eyes with early age-related macular degeneration with or without contralateral late age-related macular degeneration. Retin-J Retin Vitreous Dis 27:879-890

70. Husain D, Kramer M, Kenny AG, Michaud N, Flotte TJ, Gragoudas ES, Miller JW (1999) Effects of photodynamic therapy using verteporfin on experimental choroidal neovascularization and normal retina and choroid up to 7 weeks after treatment. Invest Ophthalmol Vis Sci 40: 2322-2331

71. Rüther KB K, Schwartz R, Hassenstein A, Richard G (2003) Testing central retinal function with multifocal electroretinography before and after photodynamic therapy. Ophthalmologe 100:459-464

72. Catala-Mora J, Castany-Aregall M, Berniell-Trota JA, Arias-Barquet L, Roca-Linares G, Jurgens-Mestre I (2005) Multifocal electroretinogram and age-related macular degeneration. Arch Soc Esp Oftalmol 80:395-404 


\section{3}


73. Moschos MM, Panayotidis D, Theodossiadis G, Moschos M (2004) Assessment of macular function by multifocal electroretinogram in age-related macular degeneration before and after photodynamic therapy. J Fr Ophthamol 27:1001-1006

74. Feigl B, Brown B, Lovie-Kitchin J, Lee L (2005) Dynamics of retinal function after multiple photodynamic therapies in age-related macular degeneration: a report of cases. Doc Ophthalmol 111:135-148

75. Moschos MM, Brouzas D, Apostolopoulos M, Koutsandrea C, Loukianou E, Moschos M (2007) Intravitreal use of bevacizumab (avastin) for choroidal neovascularization due to ARMD: a preliminary multifocal-ERG and OCT study. Doc Ophthalmol 114:37-44
76. Maturi RK, Bleau LA, Wilson DL (2006) Electrophysiologic findings after intravitreal bevacizumab (avastin) treatment. Retin-J Retin Vitreous Dis 26:270-274

77. Feigl B, Greaves A, Brown B (2007) Functional outcomes after multiple treatments with ranibizumab in neovascular age-related macular degeneration beyond visual acuity. Clin Ophthalmol 1:167-175

78. Parravano M, Oddone F, Tedeschi M, Lomoriello DS, Chiaravalloti A, Ripandelli G, Varano M (2009) Retinal functional changes measured by microperimetry in neovascular age-related macular degeneration patients treated with ranibizumab. Retin-J Retin Vitreous Dis 29:329-334 